\title{
ESSAY
}

\section{The Incarceration of Kindness}

\author{
Treacy Ziegler \\ Prisoner Express, Project of Center for Transformative Action, Cornell University, US \\ treacyziegler@yahoo.com
}

The question is not whether kindness exists in prison, it does. Instead, my question in this essay is not if but how kindness functions; understanding kindness not based upon the idiosyncratic virtues of an individual but how the community and structure of prison enables or hinders kindness.

To explore how kindness exists within prison I asked prisoners participating in the Prisoner Express project to describe four different experiences involving kindness. (PE is a distant learning project for which I am the volunteer art director, providing courses for 6500 prisoners throughout the United States and to whom I send several newsletters a year.) In one newsletter, I invited prisoners to describe: Kindness that felt sincere; kindness that seemed masquerading for something else; kindness that began with sincere intention, but got misinterpreted and misdirected into another action (often violence); kindness between a prisoner and staff or volunteer; what I refer to as "across the border" kindness.

In understanding the phenomenology of kindness in prison, this essay examines both the prisoners' descriptions of kindness and my own observations from teaching in various prisons for several years.

Keywords: Prison art; Prison teaching; Kindness; Prison volunteer; Distant learning; Prisoners; Violence; Solitary confinement; Death row; Closed system; Super-maximum security prison; Prison trust; Prison respect; Prison vulnerability; Correction officer

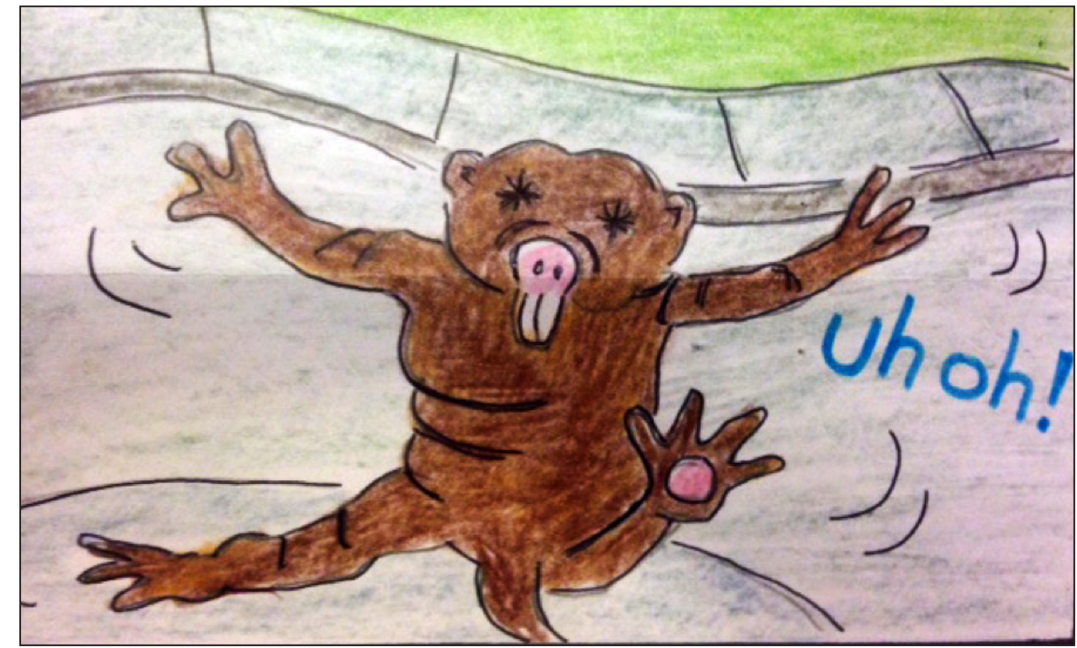

Figure 1: Farlow, Gary. Still Drawing from the Animation “The Naked Mole Rat's Journey." Produced by Treacy Ziegler, 2019, author's archives. ${ }^{1}$

Kindness makes you idle, worse, unnatural. - Douglas Oliver

\footnotetext{
1 See Rachel Heidenry, “'Without the Wall' Explores Identity and Incarceration at Philadelphia's City Hall." Art Blog, 9 July 2014, www. theartblog.org/2014/07/without-the-wall-explores-identity-and-incarceration-at-philadelphias-city-hall/. Accessed 10 Dec. 2018.
} 


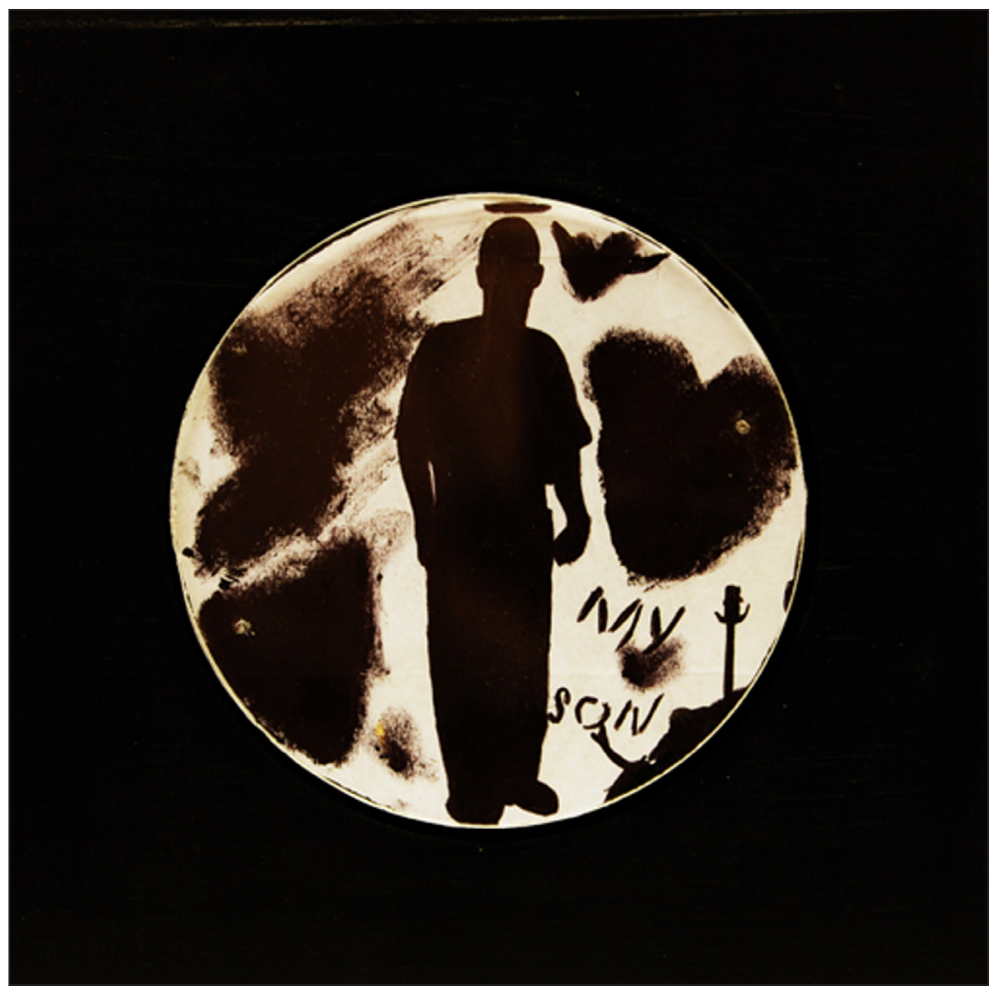

Figure 2: Machias, Armando. Drawing in "Without the Wall" Art Exhibition. Philadelphia City Hall, 2014, author's archives.

Richie is a student in my art class where I had been volunteering at a high security prison. Walking with other prisoners through the prison yard to the building that houses the class, he pushes a metal walker upon which he is dependent. Richie's legs are unable to stand on their own. I do not know the cause of his disability. The fact that we are in prison makes me assume this disability is the result of violence rather than a congenital problem such as cerebral palsy. Other than location, I don't know why I make this assumption. When Richie reaches the stairs, he cannot maneuver up on his own. One prisoner takes Richie's walker while another prisoner lends him an arm to lean upon while he ascends the stairs. This is not the first time I've seen prisoners helping another prisoner-particularly prisoners with handicaps attempting to traverse the landscape of prison. There are few efforts to make this landscape friendly to anyone. I am struck with the automatic help given to Richie. There is no hesitation in the prisoners' help to Richie and Richie does not hesitate in accepting.

As a volunteer art teacher in prisons of several states, I've witnessed a number of these acts of kindness between prisoners-perhaps, acts that could be seen as random personal acts of kindness. However, the more I observe, not only does kindness seem less random, it seems less the domain of a single person. This confuses me. I had always thought of kindness as an attribute of an individual, clumping kindness with anything that can be said about a person, "... tall, lanky, and very kind."

Prison changed that understanding for me. Instead, kindness seems to be dependent upon an underlying structure or system. Moreover, it seems necessary for that community to interpret kindness: If someone is kind to me for no clear reason, I might question whether it is kindness or not; whereas if someone punches me in the nose, the violence of that punch is clear, regardless of the why. Not knowing the dynamics of the kindness shown to me, I must look to the context.

Of course, I am but a volunteer observer. How do prisoners understand kindness in prison? I asked this question of prisoners participating in a through-the-mail ${ }^{2}$ program in which I create art curriculums for prisoners across the United States. The prisoners receiving the newsletters and participating in projects represent every state and approximately 1000 prisons. I have greater freedom asking questions in the newsletter than I do while teaching in prison workshops where my conversation is restricted.

${ }^{2}$ See "Prisoner Express Art Programs," Prisoner Express, prisonerexpress.org/programs/arts/. Accessed 10 Dec. 2019. 
In a newsletter sent to 2500 prisoner participants (this number has more recently grown to 6500), I asked the prisoners to share four different situations of kindness they might have experienced or observed:

Kindness that felt sincere;

Kindness that seemed masquerading for something else;

Kindness that began with sincere intention, but got misinterpreted and misdirected into another action (often violence);

Kindness between a prisoner and staff or volunteer; what I refer to as "across the border" kindness.

Just to be clear-all my questions were informal inquiries and not a research project!

While I don't want to undermine the prisoners' answers-about 50 prisoners answered the questions-I have to consider their answers in the context of prison where anything written or said can be used against the prisoner in a parole hearing. I often encounter posed-for-parole answers while teaching in prisons. When prisoners answer my question as to why they want to take the art class, they frequently answer; "I want to better myself," I want to express myself," and so on. Sometimes when I challenge these answers by asking "Yeah, but why really?" I get different answers:

"I want to make money," "I want to hang with the tattoo artists in class," and other less than ideal-ridden answers.

In some cases, in answering the questions prisoners described themselves as the person being kind. Most letters are screened by the administration and it is probably wise to sound like a kind person to the administration. Later, when I asked prisoners similar questions but substituted violence for kindness, no one had any violent experiences to contribute. Of course, Logan answered that I was insane to even asked such a question, saying:

\section{"No one in here wants to write about witnessing or participating in violence."}

The prisoners' answers to the first question of "sincere acts of kindness" described prison kindness in two ways; kindness as giving something tangible and kindness that was intangible. It seems understandable in prison where prisoners are required to live with so little personal belongings, kindness is experienced as sharing material goods. They shared clothes, toiletries, food, coffee, and so on. On the other hand, intangible kindness included empathy, concern, respect, encouragement, and other acts of goodwill.

John writes about being without any materials goods when he was first incarcerated and another prisoner offered him things with which to get by:

"I had a bad run-in with one of the ranking officers and was locked up and had all my property taken from me. I didn't even have a toothbrush or toilet paper. Another inmate in lock-up saw how bad a shape I was in and just gave me a toothbrush, toilet paper, and other items I needed. He did not want anything in return. He just said, "Man, I've been there."

Likewise, Davell describes the kindness he received after being released from a week in solitary confinement:

"After a week in Ad seg, I was released to general population and in serious need for some deodorant. Fortunately, I had a book of postal stamps that at half price sells for five dollars. All my personal property was in receiving and release. If I was lucky, I'd be getting it the next day but for the time being I needed to barter a book of stamps for a deodorant. I was escorted from Ad seg and housed in a 8-man cell. I made the $7^{\text {th }}$ man. There was only one man in the cell as I entered. My first thought of him was he is a lame. So I sat on my bunk and waited to meet the other guys when they got in. The second guy I met gave off a scent of a guy who has been through the prison sentence and knew what time it was. After we introduced ourselves, I showed him my paperwork and ran down to him why I was in ad seg (a misunderstanding). I told him I needed a deodorant, that I had a book of stamps. He provided me with a deodorant and let me sport his brand new tennis shoes until I got some from inmate laundry. I was moved by his kindness ... when I was issued my property I returned to the cell with all my stuff and I replaced what I got. It was my birthday and I was planning to cook a prison feast, so once I got situated, I cooked enough for the both of us. As I'm writing this, my allergies have been acting up and this same guy gave me a bottle of eye drops and a bottle of allergy tablets. That was kind." 
Bradley tells me (Bradley is a prisoner in one of my classes):

"I have a lot of money, so I try to give something to others." I don't know where Bradley gets his money and to what extent this makes his life less stressful, but I see how he helps younger prisoners in my class.

Sometimes the exchange of money is not directly given to the needy prisoner but to a third person acting as intermediary. David writes:

"I had a celly who was 'riding' or paying protection by sex acts or washing clothes, etc. to a gang. One of my friends gave me the money, $\$ 100$, to 'buy' my celly's freedom from the gang under the condition that he remain anonymous to all." (I'm not sure why an intermediary was needed in this situation and David doesn't explain.)

Many of the prisoners who answered these questions are/were in solitary confinement and Brian writes:

"I am housed in a maximum-security federal prison. Acts of kindness are very very rare to say the least. Most kindness is perceived as a weakness and taken advantage of immediately. You walk into a housing unit and you stick out ... you're the only one in the room with bright orange deck shoes. You are being sized up and odds layed on if you'll make it a week or not. Then a few guys will pool together and put a care package/starter kit bag together for you. It's a one-time shot and usually only if they think you might make it. It's a no strings attached bag containing soap, shampoo, razors, clothes matching the colors of everyone else, and maybe coffee, soup, crackers, enough for a snack if you miss a meal your first couple days ... stuff until you're situated and figure out a schedule."

When Brian describes the pooling together of a care package, there seems to be a structure for this empathy. Of course, living in this situation of being without basic things could just as easily create-and does create-a community of stealing. I wondered what enables a group to be givers instead of a group of takers?

In describing intangible kindness-empathy, listening and so on-Armando living on death row writes:

"I was in isolation. We couldn't see each other. Only hear each other. There was a skinhead and a Black homosexual next door to him. The Black homosexual was very depressed and on the verge of suicide. So the skinhead shared some of his smuggled-in coffee with him. Told him, he don't like the gay stuff but would talk to him the days he was there. He'd encourage him (the Black prisoner) to stay strong. The reason was obvious. He did it outta of kindness. That skinhead did it often in a respectful way without making it seem like charity conversation. He'd listen."

In reading Armando's description, I wonder, "What makes listening charity? And what stigma is placed on this?"

As in the general culture, kindness in prison appears to be made of similar elements-respect, giving, helping, listening, and the feeling of goodwill towards another, compassion. That kindness can happen in prison is not the question-it does. Instead, my question is not if but how kindness functions; understanding kindness not based upon the idiosyncratic virtues of an individual but how the community and structure of prison enables or hinders kindness. It seems to me that kindness in prison is most likely hindered not because prisoners are a bunch of unkind people. Instead, it seems that kindness is hindered because prison creates a single identity for the prisoners and then institutionalizes hate for that single identity of inmate. How does this institutionalized hate make kindness suspect between individuals, thus making kindness/lack of kindness not a function of an individual, but of a system? This is a question I explore along with the prisoners' answers to the second question-describe experiences in which a prisoner was pretending to be kind to others for their own alternative gain.

\section{Kindness as hostage}

On my first trip to the men's super-maximum security prison, I see a high stonewall building perched over distant trees. There is something surreal in the sight of this fortress-like building with its small windows on a lovely country road surrounded by trees and I think of Rapunzel. When I subsequently meet the prisoners in my art class, the image of Rapunzel is in strange contrast with the men, most of whom have shaved heads. 
I mention how the prison on the hill sparked the image of Rapunzel for me. One prisoner shrugs, suggesting that if he could actually see out of his cell's small window, he would be happy.

With their rural locations, high walls, and barbed wires, it's not particularly profound to say prisons are closed systems. However, it is not the barbed wires and high walls creating the strongest locks for the prison. Instead, the prison is a closed system because of the psychological isolation created for its inhabitants; created through developing the single and absolute identity of those inhabitants as inmates. It doesn't matter if that individual is a husband, father, mother, son, daughter, sister, and so on. In prison, the only identity granted to the prisoner is as inmate. A very closed system indeed.

Closed and open systems were terms describing families when I trained as a family therapist at the Philadelphia Child Guidance Clinic (where I worked as a social worker before leaving social work and entering art school). In a closed family system, the family had rigid ideas dictating how each member should act and followed strict expectations for mothering, fathering, being a wife, a husband, and a child. In the most closed of families, these rules became more important than meeting the needs of individuals in that family. With needs not met or acknowledged, behavior and psychological problems emerged and the family was often referred to the Child Guidance Clinic. Of course, this is a very simplistic interpretation of families and behavior. Most families have pre-conceived ideas of what constitutes a family and what their members should do in fulfilling these roles. However, when faced with real experiences-faced with the ambiguity of actual living-most families adjust and change their expectations; albeit, sometimes with the help of therapy. Likewise, a society functioning as an open system enables the redefinition of what constitutes a family with the changing needs of societal members. In other words, open psychological systems of families and society become fluid in order to meet the very diverse and changing needs of its members; thus, changing rules to fit those needs.

Prison, of course, is not a family. But like a family, prison is required to participate in the everyday intimacy of the individuals living there. Unlike a family, prison is not required to respond and assist to the changing needs of those individuals. Prison operates upon the absolute principle of isolating out individuals who society deems as bad. Therefore, prison's main rule is to maintain a single unchanging identity of the individual-an inmate. As the ultimate closed system, prison can ignore the ambiguity and nuances characterizing people. More importantly, prison is dependent on this unchanging identity of inmate for its very survival.

When I ask prisoners if they ever think of themselves as other than inmate, the most frequent answer is, "When I am sleeping." However, living with prisoners on a daily basis, the prison staff could be expected to eventually recognize those individuals as more complex than inmate. What then prevents many guards and staff from seeing prisoners as full people, capable of a complexity beyond "bad"? The inevitable complexity of being seen as human is prevented through the institutionalization of hate directed at an inmate; institutionalized both in prison and in society. Hate becomes the active element in keeping the label of inmate intact.

That a proportion of the public do not like prisoners (I don't know to what extent, but sizable to maintain the system as it is) is certainly not surprising. The hate for prisoners outside of prison can be seen by the responses to activities in which prisoners are able to express themselves outside the single identity of inmate. One recent example is the art exhibition of Guantanamo prisoners; ${ }^{3}$ there was controversy over this exhibition, a possible threat, and then the exhibition was closed.

In one prison where I volunteer, the administration does not make public the supportive and creative programs they develop for the prisoners. The program director says, "It's better to keep things somewhat quiet instead of making them public through media outlets like newspapers and such. Several programs I have started were cancelled when the public read about them and became outraged-even though the projects were privately funded and didn't cost taxpayers' money."

While it may be assumed public complaint is about money spent for prisoners' enrichment, the real anger seems to be about expanding the identity of an inmate. In making a film about a particular prisoner, I got not only permission, but also the enthusiasm of the prison warden and captain of security. When I arrived at the prison on the morning of the film shoot, I was stopped from making the film. A victims' rights' group objected to the project, complaining that they, "didn't want any inmate to be seen in a positive light."

Of course, it certainly does not come as a surprise that hate for prisoners exists within prison and no surprise that this hate is most often vocalized by guards.

\footnotetext{
${ }^{3}$ See Susan Edelman and Chris Perez, "Controversial Gitmo Art Exhibit Closes After Snapchat Threat." New York Post, 11 Dec. 2017, nypost.com/2017/12/11/controversial-gitmo-art-exhibit-closes-after-snapchat-threat/. Accessed 10 Dec. 2018.
} 
In an upstate New York prison where I volunteered for almost a year on a weekly basis teaching nine-hour days, I heard guards repeatedly say, "I hate inmates!" I heard this phrase so often it seemed as if it was the prison's mantra. When I heard the captain of security emphatically state it, I understood how the other guards were emulating their captain-it was the expected voice of the guards.

One guard took his hatred to the extreme, adding that he hated all Blacks-using the derogatory term. When I didn't respond with the emotional rise he wanted, he then described the several anger management courses he was required to take because of his violence to prisoners in five years as guard. When I flatly commented that I couldn't imagine anyone wanting to hire him, he replied, "I'm exactly the CO they want." And he was probably correct.

But hate does not only exist in anecdotal material of guards' treatment to prisoners. Hate has been institutionalized by the prison system through its rules and regulations dictating non-prisoners' behavior towards prisoners. Obviously the rules do not instruct hate towards the prisoners. Instead, regulations transmute hate through the insistence that prisoners are never to be trusted. The primary rule in every prison in which I have volunteered-seven prisons in four states-is "never trust an inmate;" dictated on every page of my volunteer handbooks citing all sorts of scenarios in which the inmates will trick me into doing things for them through their acts of niceness. Trickled-down hate is the result. While there is civil behavior between some guards and prisoners, overt trust of an inmate, unlike overt hate, is against every rule in every prison. Hate for prisoners is not against the rules.

Consequently, kindness is never a simple act of kindness. Kindness in prison becomes a powerful act of deviance against institutional mistrust and hate. Kindness seems to create a network of solidarity. That sense of solidarity is what I felt watching prisoners help Richie up the stairs. It is what I feel when I hear one prisoner complimenting another prisoner on their artwork or in sharing materials. It is more than one person acting alone in kindness towards another-it becomes a statement addressed to a larger issue of hate.

Kindness has the potential to become powerful in a way that violence cannot. Unlike violence, kindness cannot be controlled. There would probably be no throwing someone in the hole for being too kind, unless it can be redefined as other than kindness-as seen in the answers of the prisoners.

Prison, particularly, guards, seem to intuit the danger in kind acts. Sensing a danger existing in prisoners acting kind with one another, the guards create situations that instigate violence.

In the super-maximum prison, there are two sets of prisoners. Half of the prisoners are required to dress in grey uniforms and the other half in green uniforms. When I asked the administration why the prisoners are dressed in different colors, I am told that they live in different parts of the prison. The division has nothing to do with security rank-merely geography.

This division, however, results in constant fighting between the two sets of prisoners-so much that one group has to be totally ushered off the classroom floor before the other group arrives. If wearing different colors provokes such violence, then I wonder why officials do not just give everyone the same color uniform. It seemed such an obvious solution to the fighting, making me wonder that it might serve the prison in some way to maintain violence between the prisoners.

I've seen guards at other prisons act in ways to provoke prisoners. In one prison, guards repeatedly come into the art class reminding me of the crimes my students have committed:

"Inmate $Z$ threw his wife off the cliff, or inmate $X$ torched his victim and watched him die." This happened so many times until I asked one guard, "This is a maximum security prison. Did you really think the inmates are here because they downloaded a couple DVDs?" Thus, making his comments a bit naïve.

Violence can be controlled by more violence, but kindness cannot. How does a system control kindness? What about the solidarity created by kindness?

Even outside prison, kindness is often difficult to ascertain. Ambiguity seems to be an element of kindness demanding trust of its participants toward each other. Trust is part of kindness because actions involved are vague and can be masking something else. Because of this-that kindness can act out other emotions other than good will-kindness must be faithfully accepted as kindness to be kindness. If someone feels that kindness is being forced on them, those actions can no longer be defined as kindness.

How will be kindness be known? Consider that punch to the face again. While perhaps motivated by something other than violence, at the moment of impact, that punch will be felt as a violent act. Kind behavior is not explicit in the same way; the person may not know how he/she feels about actions of kindness directed at them. 
Given the ambiguity of kindness, what happens to kindness in a closed system where there is little or no room for interpretation? In a system that fears ambiguity, interpretation becomes misinterpretation and kindness is always held suspect. As Logan writes, prison is filled with misinterpretations:

"The incidents of this (masq kindness) are far, far to numerous to single out any given one, Treacy! Masquerading kindness" is the primary foundation of probably 80 percent of the Con-games played in prison."

Robert describes an example of someone using kindness for other gains:

"In the first few months being off death row, I went on an extreme learning curve that in many ways is disturbing and enlightening. I watched disturbing events between two people. One was a smallish white boy named Quintan and the second was a want-to-be gangbanger named Terrence-he likes to be called Murder. Quintan has some seriously distasteful charges and everyone knows it and to make things worse he is smallish and does not get any money so he is always bumming cups of coffee and things like that. Murder had been watching this for a while and he started to give him coffee here, soups, there, and after awhile started letting $Q$ eat with him and become real friendly. That didn't last long because all this kindness Murder was giving him wasn't for free. Murder finally braced " $Q$ " and wanted sexual favors from him. I won't go into detail because some things aren't for the free world. I will say that $Q$ stayed strong and wouldn't give in."

Prison does not recognize change-inmates are always inmates; always identified by their crime no matter what they do subsequently different. Therefore, with no other network for reality checking, do prisoners come to believe in the same principles as the prison, believing that change is impossible? I wonder, in reading the following description of his relationship to another prisoner, if the other prisoner deceived Tony from the beginning as Tony suggests, or did the nature of the relationship change over a course of ten years? It seems possible that intimate feelings could be developed over time and not a ploy from the beginning. Tony writes:

"In here we live in a close environment so we build close relationship. There was a friend (Black). In here you were told who we can hang around with. Well, never let anybody tell me what to do. I'm not this bad ass guy. So anyway we became close friends (the Black guy and him) and we talked all the time. We made sure we did not need anything. At this time my Dad was still alive so I never had to ask for money. Saying that, I did not need any friend looking out for me. Our friendship lasted for years (10) and I believe we had a real friendship. One that would last in and out of prison. Well, it turn out that this Black guy was just trying to get close for other reasons (sex). I know your saying 10 years I should have known. In here people do a lot of bad things not just what got us in here. So in a way I was trying to help him change his life. So yes, I did know his past life. When I found out that he wanted something else, I was so ma. I wanted to hurt him bad, but I just walked away. I never talk to try to see him when he was around."

Much of human experience demands nuanced interpretation and given its ambiguity, kindness demands even greater nuance. Without nuance, interpretation of kindness easily slips into mistrust. This leads to the third question I asked of prisoner-kindness turned into violence.

\section{The slippery slope of kindness}

In a windowless classroom of the super-maximum security prison, I sit alone with Marc waiting for other prisoners to arrive. I'm surprised to see Marc at this super max prison. He was in my prison art class at a medium-secure prison where I also volunteered. I had just seen him the month before and don't know why he is now at this higher security level prison. I don't ask.

The other prisoners never arrive for art class. This is not particularly surprising as guards at this prison often test my reactions to certain situations: I've been locked in a room with lifers-those prisoners with life sentences-where I am given no means of getting out of that room. At other times, the guards "forget" I am having a class. They don't issue call-out passes for the students and I sit there for an hour waiting for no one. I figured this time the guards locked me in the classroom with Marc to see what I would do (Who knows what they suspected!?) The guards' ploys against volunteers are numerous. However, I'm not particularly bothered by this incident; happy to conduct a private drawing lesson with Marc. He is a talented artist and works hard in the class. As Marc works on his drawing, he explains why he's in the super-max. He was 
involved in a fight with another prisoner at the medium-secured prison. Marc says, "I beat him up pretty bad. I was just trying to be kind to him, but the guy misinterpreted me ... and then it went really bad." Ronnie tells another story describing, kindness-gone-wrong:

"I was comfortable working as a janitor because it helped keep my locker full. The new guy was a pretty big youngster from Austin, Texas. He did not have any possessions when he came. Out of kindness of my heart I told him that if he was hungry to just get something out of the locker. Then I went back to work. That act of kindness was soon interpreted as an act of weakness. In the days to come he started to try and assert dominance in the cell. So I pulled him to the side and warned him that he was playing with fire and when you play with fire, then you are bound to get burned. But he brushed my warning to the side and continued to flex his muscles. After three strikes, I sent him to the hospital where he stayed in a coma for nine days."

There are numerous stories of misguided kindness. Logan writes:

"I had a Christian cellmate (known as Jesus) who was 'generous to a fault' as they say, especially for the penal environment. One day (after he'd had 3 radios of his stolen because he'd never stand his ground to get one back) he noticed this new African-American prisoner (about 23 years old) didn't have a radio. So he tells me, 'The Lord is moving me to give that kid a radio.' Against my advice, this cellmate went to the kid's cell, handed him a radio and said, 'Here, this is for you. Jesus loves you. Remember that!' Well, the kid was stunned of course so after he thought about it, he (a recruit for the Crips) goes to the Crips and asks, 'What do I do?' They tell him to beat the hell out of him. The kid's first blow was smashing the radio across his face."

Armando speaks of an incident of kindness interpreted as an insult by the person receiving kindness:

“There is one man who's always in arguments and thinking he's being picked on. When I share thoughts in a nice way, he interprets it as a sarcastic remark. What was a sincere comment becomes ridicule. If you give him food, it becomes an innuendo of being a bum or poor; soap becomes a subtle sign that he stinks; an offer becomes a trap. Etc.etc. Kindness can become suspect to a paranoid mind. Truth is, often times people give but consciously or unconsciously they expect something in return. You hear it in the remark "After I've done for you ..."

Simple acts of kindness can be misinterpreted. Scooter writes:

"One time I was trying to be kind to someone and it almost cost me my life. It was mail call and the boss we had working the tank doesn't like inmates. If she called your name for mail and you didn't hear her you would not get your mail that day. I was standing there waiting on her to call my bin number when she called one of my neighbors. So being a nice guy I got his mail and took it to him. He got all bent out of shape because I handled his mail and he decided to pull out a shank and tried to stab me. Needless to say, I learned my lesson about touching other peoples' things (hah)."

In these descriptions, kindness is interpreted as weakness with the opportunity to take advantage of the other person. But that's the thing; kindness does demand vulnerability. Kindness demands a vulnerability-call it weakness-of both parties; the giver, who is extending him/herself to someone who might reject the offering; and the receiver, who by accepting kindness, admits a need.

One of the difficulties is that there are no rules on how kindness is to be exchanged between two people. This lack of rules for kindness stands in contrast to how respect can be developed in prison. Gaining respect in prison has a specific structure based upon rules dictating the behavior of the individuals. It is a structure upon which-according to the prisoners in my classes-many prisoners grow dependent. But as Fred, a student in my class, suggests;

"When they get out, they try to find this same formula for getting respect, but don't get it and this becomes hard on many. They get angry on the street, often act out in response, and then get sent back in here." 
Unlike respect, kindness is a funny thing. It cannot be formulized into the same "if this, then that" equation that is possible in respect development. An element of kindness is the lack of personal gain for the giver; my actions cannot be considered kind if my actions are for my benefit. Nor can kindness be formulized into rules dictating how I should act in a certain situation; I cannot be forced into acting kind. Likewise, rules dictating how the receiving person must react to my kindness also undermine the experience of kindness. Kindness asks to remain uncharted, unexpected, and unpredictable-a difficult task in a system that imposes rules upon every aspect of a prisoner's life.

\section{Kindness across the border}

What happens when volunteers and non-prisoners mingle with prisoners? How does kindness get interpreted between those living exclusively in a closed system with those living in the more open system of society?

As mentioned earlier, the basic rule for volunteers is not to trust prisoners. However, volunteers do not usually come to prison because they hate prisoners; quite the opposite. More often, individuals volunteer in prison through humanitarian concerns of which trust is a basic element. In fact, mistrust is often counterintuitive to many volunteers and it is easy to see how the volunteers can be a major problem to the prison, needing constant admonishment for their potential trust of prisoners.

While teaching an art prison class in a high security prison, I developed a migraine. Unable to get medication from the infirmary, I had the dilemma of whether to tell my prisoner students about the headache. Not telling them and pretending I feel ok, makes it more difficult to teach. However, in telling them, I make myself vulnerable; putting myself somewhat at their mercy. I chose to tell them, adding, "Think of me as the queen where you have to bring your drawings immediately in front of my face so I don't have to turn left or right. It hurts so much to move my head." The prisoners think my request is funny, but they comply displaying their drawings immediately in front of my eyes. It is kind of funny, when suddenly I see out of the corner of my eye, two pills set on the table next to me. I can't see who put them there, but I sense they are ibuprofen or such painkillers, and feel a rush of relief. I almost move my arm towards them but immediately catch myself, thinking, "What is taking medicine from a prisoner-a felony?" The experience makes me question the strange institutionalized structure of prison where kindness becomes a felony.

What are other forms of kindness crossing the border between volunteers and prisoners that may violate the volunteer handbook? Is sharing laughter an expression of kindness? It is reported by a research for Stanford Business school, humor creates a bridge between individuals because laughter "sparks the release of oxytocin, a hormone that facilities social bonding, increases trust and quickens self-disclosure" (Stein). I remember a prisoner in the super-maximum security prison stating, "If it wasn't for the volunteer, prison would be totally intolerable." He made this statement in response to on-going laughter in the class.

Lisa Daigle, a volunteer in a New England prison, spoke of laughter as a constant element in her class. When I recently asked Lisa about this, she wrote;

"Laughter and humor are a shared language that create a bond between inmate and volunteer. This language creates a space where deep feelings can emerge, as laughter opens up our vulnerable side. Laughter and humor also add brevity when the topics get heavy. Some inmates are distrustful of each other, and laughter helps ease the distrust and elicits common humanity. The anticipation of fun also draws inmates to return to classes as they can count on having fun in an otherwise challenging existence; at times, it seems that they forget where they are. And, when volunteers laugh, it feels like we are more like them, which is simply to say that we are all people, and that we are more alike than we are different. Sometimes, though, when the laughter dies down, the room becomes somber, because the inmates do remember where they are. And, they know that the volunteers are feeling that in the space that emerges after the laughter.

Prison guards were particularly skeptical of laughter in my classroom, suspecting it would develop the trust prohibited in my volunteer handbook. They were correct; it did allow trust.

Obviously, relationships between guard and prisoner are much more tested through daily living than those between volunteer and prisoner. Even so, I saw some guards acting compassionately with prisoners. I did not see much compassion directed at the guards from the prisoners. A reason for this may be summed by a poem written by Les Ames, serving life. In his poem entitled "The correction officer of light" Les writes: 


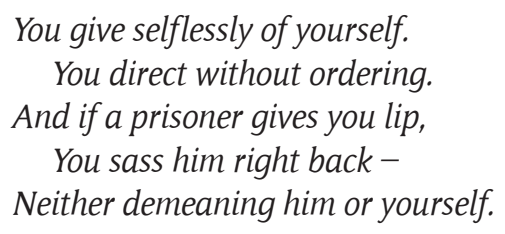

Les continues describing the guard's compassion and ends the poem:

$$
\begin{aligned}
& \text { Yet, if I display too much praise } \\
& \text { And affection for you and others, } \\
& \text { I will be locked in the hole } \\
& \text { for singing a blatant love song } \\
& \text { or, for being gay in more than spirit. }
\end{aligned}
$$

Guards do not seem to trust kind actions of prisoners directed towards them.

I did see more compassion of guards for prisoners in one mid-west prison. I don't know how race influenced this relationship. The warden and the program director were both Black men. When I asked the program director about the prison's more gentle approach of the guards towards the prisoners; he replied. "It took the warden and me years to train the COs to be more empathetic to the inmates." And then he added, "It's a slippery slope to prison that anyone of us could fall into."

The only other prison where I saw compassion from guards to prisoners was on a mental health ward of a maximum-security men's prison. There were full-time social workers, psychologists, and therapists on this particular unit. I wonder if the presence of these professionals trained in empathy offered other ways of treating prisoners.

The prisoner Merle was locked in solitary on the mental health unit for three months for the offense of urinating in the janitor's closet. To my observation, it seemed peeing into the janitor's sink was evident of Merle's self-restraint compared to previous behavior; Merle had difficulty maintaining boundaries. This difficulty may have been a result of Merle being physically, mentally and sexually abused for years by his grandparents until he killed them when he was 18 years old. Apparently the administration of the prison (not the mental health staff) did not share my assessment of Merle's behavior. Instead, they saw the need for punishment. However, one day, I smelled a cigarette burning on the ward. Responding to my surprise, the guard said, "I didn't have the heart to tell Merle to put it out. He's suffering." This small act of mercy, seemingly simple, was in fact a major defiance that could have cost the guard his job.

Many of the answers describing examples of kindness across the border were kindness of guards. Tommy writes:
"One day I went to the yard. I am a very light skinned white man and on this day I stayed in the sun for almost two hours. I was burned. The next day I returned from lunch and an officer called me to the desk and there was a Sergeant with her. She asked, 'How did you get red?', then, 'Does it hurt?' She admon- ished, 'Stay out of the sun.' It touched my heart, this simple act of kindness. This was a Black female officer inquiring about the welfare of a white inmate with her supervisor standing there."

In some instances these acts of kindness are experienced with a mixture of appreciation, confusion, and disgust. James writes about a guard being kind to him. "Need more time?' Asked the sergeant, as I was finishing up my meal. Everyone else in the row I was in, had already left and the chow hall was filling up fast. 'If you do, you can move over there.' As I picked up my tray and headed out I had a ridiculous urge to cry. That a guard, and a sergeant at that, treated me as if he thought I was a human being with kindness and consideration. And respect, even. It's a sad thing to have to report that simple common decency exhibited by one man to another should evoke such an acute response. For a brief moment, I was allowed the luxury of being, for all intents and purposes, something other than a number. Immediately though, I felt conflicted. That I apparently ached for such an affirmation caused me to feel disgusted with myself for being so weak-so needy, while at the same time, savoring the experience."

David writes about a guard being kind to his mother:

"My mom was refused to visit (after driving two-hours) simply because she was wearing sandals without socks. On the way back to her car, an officer heard what was going on, went out and found my mom crying. She took her own socks off and gave them to my mom so she could visit me." 
Sometimes the guards initiate an experience of kindness by asking a prisoner to help out another prisoner. Walter wrote:

"I am usually the designated barber in whichever prison I am housed. One day a CO entered into our building with an elderly man. From first glance he appeared to be approximately 60 years old. The man's face was swollen and he had a black eye. His prison-issued clothing was bloodied and his hair was long and dirty. Then I heard my last name called loudly by the officer. He motioned me over and looked me straight in the eye, 'This man was jumped in the other building by two young punks who were in disagreement with his grooming standards. He is now a resident of this building and if anything happens to him in my building, there will be hell to pay." Walter thought "my building" was arrogant but kept quiet. "I was pissed that they had done that to an old man and I think the anger I had towards them turned into respect and love for this man." Walter describes taking care of the old man-helping him shower and found some food for him. Walter continues, "and then a strange thing happened. Dudes, hardened criminals who didn't have nothing for nobody started casing their cells and came back with things for "Pops." Dudes came over and shook his hand and introduced themselves. Pops ended up being the best chess player on the yard and never lost a tournament, representing our building. A Vietnam vet, very knowledgeable and versed on the law. Helped many dudes file writs appeals, child custodies."

A major question becomes why some guards and staff have the capacity to show kindness to prisoners? When superficially asked, some guards suggest it was their age-they mellowed out. I don't have much to conclude except that it would be an interesting conversation to have with staff.

Do sexual relationships extended across the border qualify as kindness? Some of the answers suggest prisoners saw sex as kindness, but that it also posed difficulties. Tony writes, "We used to have ladies and men come to visit us once a week through the Kiros program until the ladies started having relationships with the inmates. I'm not blaming the ladies. But it sure did hurt the Kiros program."

Clarence describes a man from the outside writing to him to be his sexual pen pal (I'm not sure how a sexual pen pals work, particularly since the letters can be read by the guards and staff.) Clarence sent me the letter, suggesting, "Give the letter to someone who is free, who may be able to share his life and wealth with them. Hopefully, he finds that someone he wishes to be with." The man who gave his name and address in the letter was actually a known politician in a mid-west community.

Sex across the border can be used to redefine a more dangerous situation. Ronnie describes a situation in which kindness across the border is redefined as sex to deflect the primary concern:
"A female guard wrote up a ticket for indecent behavior (for a particular prisoner) when a prisoner was taking a leak in his own cell when she walked by. Because of this ticket, the prisoner was denied his upcoming parole. Later when this female guard was closing the cells doors, this prisoner pulled her into his cell and beat the crap out of her. No one responded to her yells until one inmate finally went to the cell and pulled her out. For his act of kindness, this prisoner was given a disciplinary case for improper relationship with a guard."

Other times, sex is just experienced as kindness and, as David writes, perhaps an example of "tea and sympathy" helping him develop a sense of his sexual self. "Having come to prison at 20 years old and remaining here for so long (I'm now 34) I've had numerous relationships with officers. Some were innocent-women looking at me like I was their own child-other, not so innocent-as if we were lovers. Another memorable person was a woman who I had a crush on and asked her to be my first as I was a virgin and didn't want to die one. She thought I was insane, but eventually she sensed my sincerity and we became a couple. We were together for 3 of the toughest years for me, as I'd lost two relatives within a year of each other and was hurt. Knowing how much she risked to love me makes our relationship way beyond kindness."

Obviously there is subterfuge in sexual relationships between prisoners and non-prisoners that are in violation of rules. There's even a sign on the staff lounge wall of a maximum-security men's prison stating, "Do not have sex with inmates," should any of us forget. However, I can't help wonder if sexuality between prisoner and non-prisoner is actually less threatening to the prison system than simple kindness. The system may understand the dynamics of sex better than the inherent ambiguity of kindness. Maybe that is why kindness in prison is constantly misinterpreted as sex-turning kindness into something understandable.

While I have been focusing upon the phenomenon of kindness, I have been grasping at ambiguity-the incarceration of kindness but the death of ambiguity. However, exploring a phenomenology of kindness with 
the prisoners seems less obscure and ideological then asking them to describe ambiguity or lack of it in their lives. How does one describe the natural ambiguity of living? Is this an experience transmittable into words?

As an artist, I am confronted with ambiguity every time I begin a painting or sculpture. I can only follow rules up to a point: open the studio door, decide to paint a particular subject, determine the size, gesso the canvas, and so on. At some point in the process, I have to leave prescription behind in order to create; thus, bringing something new into existence. If I do not enter this uncharted area of painting, the work becomes as flat as a paint-by-number piece.

Through teaching art in prison, I observed how ambiguity plays a role in both art and kindness. In art classes, the prisoners seemed challenged when asked to draw from life; asking them to use their own eyes and draw what they see. There is no formula for this approach to drawing and it makes them uncomfortable. Instead, prisoners (and most of the public who are not trained in art) often want how-to books providing step-by-step instructions or they draw from photographs that have already translated the three-dimensional world into a two-dimensional one; a translation which demands a leap of faith for the artist.

Like the creativity in art, kindness has no ultimate how-to instruction. Prescriptive kindness, like formulaic art, is affectively flat.

But, flatness is demanded by prison. In a maximum-security prison, a yellow line is painted on the corridor floors upon which prisoners are to follow. It leads to closed gates separating corridors. At these points, the prisoners will wait in line until it is ok'd by the guards to move through the gates. Many prisoners have been walking the yellow line and stopping at the gates for years; even though some are now shadows of the person who committed the crime.

In the super-maximum-security men's prison where every aspect of the prisoner's day is prescribed, the prisoners are psychologically fragile; so much that when they drop a pencil, they yell at me saying, "you made me do that!" To their understanding, this may be true-everything in prison has a clear cause and effect. I suggest to them that in assigning me as the cause, I get to control not only when they drop the pencil, but also when they get to pick those pencils up. Without personal accountability, freedom is denied. The prisoners stop yelling at me.

Because kindness does not have a cause and effect relationship, it can easily become the enemy in a system that survives on prediction and rules. Kindness may even be seen as an act of freedom.

Kindness does not effect change. Kindness creates change; non-conforming and non-linear. Potently there and not to be controlled. What happens if kindness as a phenomenon of solidarity were to emerge in prison-could it act as a free-floating medium for social change challenging the status quo?

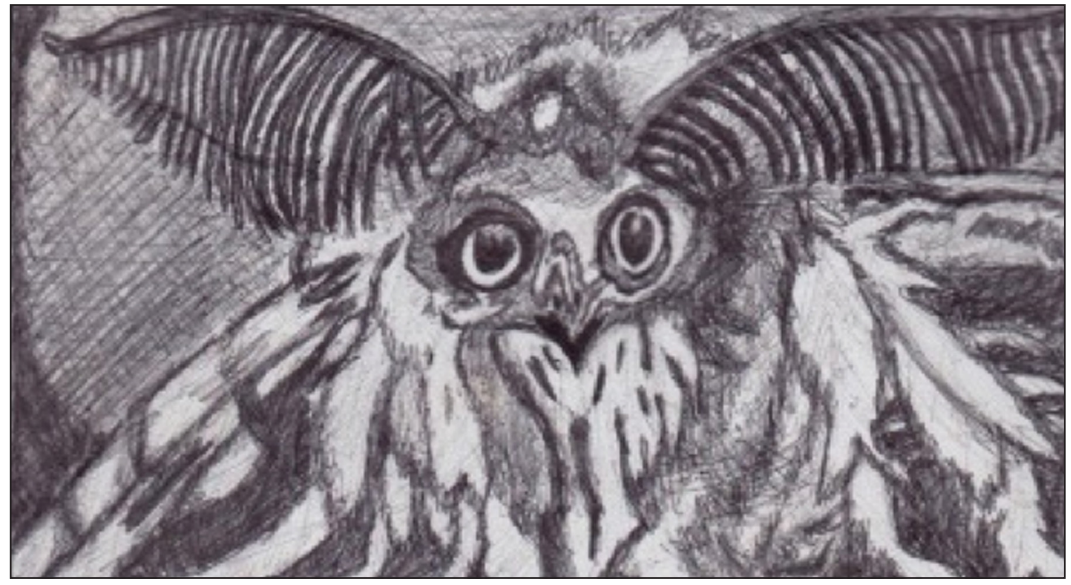

Figure 3: Washington, Jerome. Still Drawing from the animation "Moth and light." Produced by Treacy Ziegler, 2015, author's archives.

\section{Competing Interests}

The author has no competing interests to declare.

\section{Reference}

Stein, Joel. "Humor is Serious Business." Graduate School of Stanford Business, 11 July 2012, www.gsb. stanford.edu/insights/humor-serious-business. Accessed 10 Dec. 2018.

\footnotetext{
${ }^{4}$ See www.documist.com/moth-and-light.
} 
How to cite this article: Ziegler, T 2019 The Incarceration of Kindness. Anthurium, 15(2): 11, 1-13. DOI: https://doi. org/10.33596/anth.392

Published: 23 September 2019

Copyright: $\odot 2019$ The Author(s). This is an open-access article distributed under the terms of the Creative Commons Attribution 4.0 International License (CC-BY 4.0), which permits unrestricted use, distribution, and reproduction in any medium, provided the original author and source are credited. See http://creativecommons.org/licenses/by/4.0/. 